\title{
Investigating the bioavailability of phytochemicals and minerals from broccoli soups
}

\author{
T. Sivapalan, A. Melchini, M. Traka, S. Saha and R. Mithen \\ Food and Health Programme, Institute of Food Research, Norwich Research Park, Norwich, NR4 7UA, UK
}

Cruciferous vegetables such as broccoli are associated with a reduced risk of different types of cancers ${ }^{(1)}$, cardiovascular diseases ${ }^{(2)}$ and other chronic diseases. This is attributed to the active phytochemical sulforaphane (SF) hydrolysed from glucoraphanin, a glucosinolate found in broccoli ${ }^{(3)}$. SF is a potent inducer of $\mathrm{Nrf} 2$, a transcription factor which upregulates anti-oxidant genes and has lately been shown to modulate central metabolic pathways ${ }^{(4)}$. We have developed broccoli varieties with allelic variation in Myb28, a key transcription factor in glucosinolate biosynthesis, and are using these to deliver increasing levels of glucoraphanin in human dietary intervention studies. The aim of the current study is to assess bioavailability of SF and other minerals from soups containing these novel varieties.

The study was designed to recruit ten healthy participants (male and female) aged 18-65 years old into a randomized, doubleblinded, three-phase crossover intervention trial. Plasma and urine samples are collected at various timepoints after consumption of one of the three types of soup (standard $\left[\mathrm{Myb}^{-/-}\right]$, Beneforte ${ }^{\circledR}\left[\mathrm{Myb} 28^{\text {vill/ }-}\right]$ and Beneforte Extra broccoli $\left[\mathrm{Myb} 28^{\text {vill/vill }}\right]$ ). Total SF, free SF, and its conjugates (SF-glutathione, SF-cysteine-glycine, SF-cysteine and SF-N-acetyl cysteine) was measured using liquid chromatography-mass spectrometry method stated by Gasper et $\mathrm{al}^{(3)}$ and cyclocondensation based on the method of Ye et $\mathrm{al}^{(5)}$. Inductively coupled plasma mass spectrometry was performed according to the method used by Hurst et al ${ }^{(6)}$ to analyse total sulphur and other minerals in the broccoli soups, urine and plasma.

\begin{tabular}{|c|c|c|c|c|c|c|}
\hline \multirow[b]{2}{*}{ Micronutrients } & \multicolumn{2}{|c|}{$\begin{array}{l}\text { Standard broccoli and } \\
\text { stilton }\end{array}$} & \multicolumn{2}{|c|}{ Beneforte broccoli and stilton } & \multicolumn{2}{|c|}{$\begin{array}{l}\text { Beneforte Extra broccoli and } \\
\text { stilton }\end{array}$} \\
\hline & Mean & $\mathrm{SD}$ & Mean & SD & Mean & SD \\
\hline Glucoraphanin ( $\mu$ moles/100 g Fresh Soup) & $14 \cdot 17$ & 0.78 & $53 \cdot 26 * * *$ & $18 \cdot 12$ & $147 \cdot 47 * * *$ & 6.53 \\
\hline Total sulphur (g/100 g dry wt) & $287 \cdot 33$ & 11.93 & $442 \cdot 33^{* * *}$ & 8.96 & $556 \cdot 33 * * *$ & $14 \cdot 01$ \\
\hline Iron $(\mathrm{mg} / 100 \mathrm{~g}$ dry wt) & $0 \cdot 99$ & $0 \cdot 02$ & $2 \cdot 07 * * *$ & $0 \cdot 05$ & $3.63 * * *$ & $0 \cdot 14$ \\
\hline Potassium (mg/100 g dry wt) & 0.90 & 0.05 & $1 \cdot 30 * * *$ & 0.03 & $1 \cdot 50 * * *$ & 0.40 \\
\hline
\end{tabular}

Glucoraphanin values are a mean of 10 independent soup batches. Total sulphur, iron, potassium values are a mean of 3 independent soup batches. $* * * p<0.001$ vs standard broccoli using ANOVA.

Mineral analysis of the three soups is outlined in the table which shows that Beneforte ${ }^{\circledR}$ and Beneforte extra soups have significantly higher concentrations of glucoraphanin, total sulphur, iron and potassium compared to standard broccoli. These results confirm that the Beneforte Extra and Beneforte ${ }^{\circledR}$ broccolis are able to deliver 10 times and 3 times more glucoraphanin respectively compared to standard broccoli $(\mathrm{p}<0.001)$. Analysis of SF and metabolites in plasma and urine sample are undergoing. In conclusion, the results from this study provide valuable information on SF metabolism for other future studies.

This study is funded by the Biotechnology and Biological Sciences Research Council (BBSRC).

1. Higdon JV, Delage B, Williams DE et al. (2007) Pharmacol Res 55, 224-236.

2. Zhang X, Shu XO, Xiang YB et al. (2011) Am J Clin Nutr 94, 240-246.

3. Gasper AV, Al-Janobi A, Smith JA et al. (2005) Am J Clin Nutr 82, 1283-1291.

4. Hayes JD and Dinkova-Kostova AT. (2014) Trends Biochem Sci 39, 199-218.

5. Ye L, Dinkova-Kostova AT, Wade KL et al. (2002) Clin Chim Acta 316, 43-53.

6. Hurst R, Siyame EW, Young SD et al. (2013) Sci Rep 3, 1425. 